\title{
Does Overconfidence Affect Corporate Investment? CEO Overconfidence Measures Revisited
}

\section{Ulrike Malmendier}

Graduate School of Business, Stanford University, Stanford, CA 94305, USA

email: ulrikem@stanford.edu

\section{Geoffrey Tate}

Wharton School, University of Pennsylvania, Philadelphia PA 19104, USA

email:tate@wharton.upenn.edu

\begin{abstract}
This article presents the growing research area of Behavioural Corporate Finance in the context of one specific example: distortions in corporate investment due to CEO overconfidence. We first review the relevant psychology and experimental evidence on overconfidence. We then summarise the results of Malmendier and Tate (2005a) on the impact of overconfidence on corporate investment. We present supplementary evidence on the relationship between CEOs' press portrayals and overconfident investment decisions. This alternative approach to measuring overconfidence, developed in Malmendier and Tate (2005b), relies on the perception of outsiders rather than the CEO's own actions. The robustness of the results across such diverse proxies jointly corroborates previous findings and suggests new avenues to measuring executive overconfidence.
\end{abstract}

Keywords: behavioural corporate finance; CEO overconfidence; corporate investment.

JEL classification: $G 14, G 31, G 32, D 80$

\section{Introduction}

The literature in behavioural economics and behavioural finance departs from the traditional economic model to incorporate psychological evidence on non-standard preferences and beliefs, such as loss aversion, sunk-cost fallacy, or overconfidence. While much of the evidence on such deviations is hard to dispute, it is less clear whether economists need to account for them. The ultimate purpose within our discipline, one may argue, is predicting economic outcomes rather than the correct description of decision-making processes. A key test for the relevance of behavioural approaches, then, is the explanatory power of behavioural features once we go beyond the realm of individual decision-making. As economists we are interested in market interactions. In the market, high-stake incentives and repeated transactions might 
discipline deviations (Stigler, 1958; Becker, 1957). The question is what happens in market settings where behavioural agents interact with (potentially) unbiased agents. Does market interaction foster learning and diminish those mistakes? Or does the presence of unbiased agents, who may exploit the non-standard behaviour of others, exacerbate the impact of individual biases on market outcomes?

The growing literature in Behavioural Corporate Finance provides insight into these questions in the context of corporate finance decision-making. Non-standard preferences and beliefs are important from two perspectives. The first perspective recognises that investors make mistakes which managers exploit. An example is the issuance of equity by rational managers when firms are overvalued due to investor sentiment (Baker and Wurgler 2000, 2002). The second perspective recognises that managers make systematic mistakes which markets do not fully correct, such as overinvestment. ${ }^{1}$

The rest of the paper focuses on a specific example of managerial biases: CEO overconfidence and its impact on corporate investment. We first review the evidence of investment distortions presented in Malmendier and Tate (2005a). We present supplementary evidence on the relationship between CEOs' press portrayals and overconfident investment decisions. This alternative approach to measuring overconfidence is a simplified version of the overconfidence measure developed in Malmendier and Tate (2005b). It relies on the perception of outsiders rather than the CEO's own actions. We conclude with a discussion of corporate governance implications.

\section{Overconfidence: Definition and Psychology Evidence}

The analysis of overconfidence relates several branches of the psychology literature. First, an extensive experimental literature documents the tendency of individuals to consider themselves 'above average' on positive characteristics (e.g. Kruger, 1999; Alicke et al., 1995; Alicke, 1985; Svenson, 1981). Svenson, for example, demonstrates that the vast majority of subjects rate their driving skills as 'above average'. Svenson's finding has been replicated numerous times in various countries and with respect to various IQ- or skillrelated outcomes other than driving. When asking a sample of entrepreneurs about their chances of success, Cooper et al. (1988) found that $81 \%$ answered between 0 and $30 \%$ (with 33\% attaching exactly zero probability to failure). However, when asked the odds of any business like theirs failing, only $39 \%$ of them answered between 0 and $30 \%$. Larwood and Whittaker (1977) find that corporate executives (and management students) are particularly prone to this form of self-serving bias.

The 'better than average' effect also affects the attribution of causality. Because individuals expect their behaviour to produce success, they attribute outcomes to their actions when they succeed and to bad luck when they fail (Miller and Ross, 1975; Feather and Simon, 1971). This self-serving attribution of outcomes reinforces overconfidence.

\footnotetext{
${ }^{1} \mathrm{~A}$ third, within-firm perspective analyses how higher-level management responds to biases of lower-level employees, for example by giving stock options to employees who are overly excited about the firm (Bergman and Jenter, 2005). For an overview on the 'Behavioural Economics of Organisations' see Camerer and Malmendier (forthcoming).

A fourth string of related literature analyses the interaction of firms with biased consumers and analyses how firms' contract design and product design responds to consumer biases ('Behavioural Industrial Organisations', e. g. Gabaix and Laibson, 2005; DellaVigna and Malmendier, 2004).

For a survey that covers the first two perspectives, see Baker et al. (forthcoming).
} 
The 'better than average' effect is particularly likely to apply to high-rank executives for a number of reasons. First, Kruger (1999) and Camerer and Lovallo (1999) show that the effect is especially strong among highly skilled individuals, possibly due to insufficient weighting of the comparison group ('base rate neglect'). If CEOs compare themselves to the average manager rather than other CEOs, they may conclude they are better than average at picking investment projects or merger targets. Second, the effect tends to be strongest for outcomes that are abstractly defined rather than in a one-to-one comparison with other people (Moore and Kim, 2003). CEOs will rarely have a direct comparison. Decisions such as large-scale investments are naturally complex and hard to compare across firms, making it hard to detect overestimation.

A related branch of the self-enhancement literature documents the tendency of individuals to be too optimistic about their own future prospects (Weinstein, 1980; Kunda, 1987; Weinstein and Klein, 2002). Individuals are the most optimistic about outcomes which they believe are under their control (Langer, 1975). And individuals are more prone to overestimate outcomes to which they are highly committed (Weinstein, 1980). Top corporate managers are likely to satisfy both of these pre-conditions. First, a CEO has the ultimate say about his firm's big strategic decisions and decides whether or not a largescale investment or a merger goes ahead. Such a position may induce the CEO to believe that he or she can also control the outcome - and thus to underestimate the likelihood of failure (March and Shapira, 1987). Second, a large portion of CEO compensation (stocks and options) depends on how well the company is doing. Similarly, the value of a CEO's human capital (probability of firing, outside options) is tightly related to company returns. So, for compensation and career reasons alone, we would expect top executives to be highly committed to the outcome of their corporate decisions.

Moreover, the higher up managers climb on the corporate ladder the more likely they are to face exactly the type of decision-making environment under which biases are likely to persist. Low-frequency and noisy feedback, for example, are key predictors of biased decision making (Nisbett and Ross, 1980). And top-level executive decisions such as large-scale investments, merger agreements, or capital restructuring are relatively rare events in the life of one company, and each project has many distinct features which make comparison to past experiences difficult.

In summary, there is strong support for the hypothesis that top corporate decisionmakers persistently overestimate their own skills relative to others and, as a result, are too optimistic about the outcomes of their decisions. We formalise this notion by assuming that overconfident managers overestimate the expected returns to their corporate decisions. This assumption is similar to the notion of 'hubris' in Roll (1986). It also relates to the frameworks of Heaton (2002) and Landier and Thesmar (2004), who model managers that overestimate the probability of project success. The latter authors use the term 'optimism' rather than 'confidence'. We choose the 'confidence' terminology, as in Camerer and Lovallo (1999), to draw a tighter link with the literature on excessive selfconfidence and the 'better than average' effect. Our terminology highlights the distinction between overoptimistic beliefs that result from overconfidence and general optimism about exogenous events (like the outbreak of a war). ${ }^{2}$

\footnotetext{
${ }^{2}$ There is a strong precedent in the psychology literature for using 'confidence' to describe biases in self-assessment and 'optimism' for biases in beliefs about exogenous events (see Bazerman (2002) and contrast Feather and Simon (1971) and Langer (1975) with, for instance, Hey (1984) and Milburn (1978)).
} 
Our approach is distinct from the finance literature, predominantly on stock trading, which models overconfidence as the underestimation of variance (typically of a signal of firm value). This assumption draws on the calibration literature, which shows that individuals tend to overestimate the accuracy of their information. ${ }^{3}$ There is some evidence that managers are prone to this bias (Moore, 1977). In corporate finance, this form of overconfidence has been applied to contracting with managers (Gervais et al., 2003) and succession tournaments (Goel and Thakor, 2000).

\section{Overconfidence and Managerial Decisions}

\subsection{Measuring CEO overconfidence}

The biggest challenge for the analysis of overconfidence is to construct a plausible measure of overconfidence. Biased beliefs naturally defy direct and precise measurement. In our previous work, we propose two approaches. The first is a 'revealed beliefs' argument. We infer CEOs' beliefs about the future performance of their company from their personal portfolio transactions. The second approach captures how outsiders perceive the CEO. We classify CEOs as overconfident based on their portrayal in the press.

The first approach ('revealed beliefs') requires detailed information about CEOs' personal portfolio transactions in their companies' stock and options. A unique panel data set on Forbes 500 companies, collected by Yermack (1995) and Hall and Liebman (1998), provides these details including duration, exercise price, and vesting period of each executive option package. To construct a measure of overconfidence, we exploit the high degree of under-diversification faced by CEOs in large US corporations. These CEOs receive extensive stock-based compensation, often in the form of restricted stock and non-tradable options. Moreover, their human capital is invested in their company. Thus, even modest risk aversion predicts that CEOs should diversify their portfolios, i.e. exercise in-the-money options or sell company stock on a pre-committed schedule. ${ }^{4}$

Some CEOs, however, do exactly the opposite. They hold options that are well in the money and buy, rather than sell, company stock. These CEOs bet their personal wealth on future company stock performance. One way to measure overconfidence, then, is to look at CEOs who hold options beyond rational thresholds. Calibrations of the Hall and Murphy (2002) model (with CRRA utility, risk aversion of 3, and 67\% of wealth in company stock) would suggest exercise entering the final year of duration when the option value exceeds $40 \%$. The median option held to expiration is in excess of $200 \%$ in the money. Alternatively, we look at a common year beyond the vesting period for all of the options in our sample (year 5). Here, we again use the Hall and Murphy model to calibrate a range of rational thresholds for exercise (varying risk aversion and diversification). Then, we consider the subsample of CEOs with options beyond these benchmarks and compare CEOs who exercise (rational) to CEOs who continue to hold (overconfident). The sample restriction assures that we do not contaminate the overconfidence measure with CEOs who have not yet had the

\footnotetext{
${ }^{3}$ Alpert and Raiffa, 1982; Fischhoff et al. 1977.

${ }^{4}$ Precommitment allows to avoid sending negative signals to the market. 
opportunity to display overconfidence. To check whether these exercise decisions are driven by inside information, we compute the returns CEOs earned as a result of their trading decisions. We find no evidence that CEOs earn abnormal returns by holding options beyond rational benchmarks. Indeed, it appears that CEOs who hold all the way to expiration would have been better off on average by exercising $(1,2,3$, or 4 years) earlier and simply investing the proceeds in the S\&P 500.

A second measure, proposed in Malmendier and Tate (2005b), builds on the perception of outsiders. We hand-collect data on how the press portrays each of the CEOs during the sample period. We search for articles referring to the CEOs in The New York Times, Business Week, Financial Times, The Economist and The Wall Street Journal. For each CEO and sample year, we record the number of articles containing the words 'confident' or 'confidence;' the number of articles containing the words 'optimistic' or 'optimism;' and the number of articles containing the words 'reliable', 'cautious', 'conservative', 'practical', 'frugal', or 'steady'. We hand-check that the terms are used to describe the CEO in question and separate out articles describing the CEO as 'not confident' or 'not optimistic'. We then construct an indicator, TOTALdummy, equal to 1 if a CEO is more often described as 'confident' and 'optimistic' or as 'reliable', 'cautious', 'conservative', 'practical', 'frugal', or 'steady'. This alternative indicator of CEO confidence is significantly positively correlated with our portfolio measures.

\subsection{Applications}

Our next step is to link the behaviour of CEOs on their private accounts to their behaviour on the corporate accounts. Do CEOs who personally overinvest in their company (and make losses from this underdiversification) also display overconfidence in their corporate decisions? Similarly, how does outside perception as 'confident' and 'optimistic' relate to corporate decision-making? In our previous work, we have considered three types of decisions: investment, merger, and capital structure decisions. Here, we focus on the investment setting of Malmendier and Tate (2005a) and augment it with new evidence based on our press-based measure of overconfidence.

To start with an example, consider the legacy of Roger Smith, the CEO of General Motors from 1981 to 1990 - and an overconfident CEO according to our measures. Smith believed that fully robotised plants were the future of automobile production. Plants with no human presence would allow GM to cut costs and to reduce the company's unionised labour force. He invested $\$ 40$ billion to automate GM's plants. His vision led to massive layoffs at GM. It also triggered negative responses from business analysts and engineers alike who did not believe the technology was advanced enough for practical application. Outside perception proved correct. The result of Smith's pet project was plants in which 'the robots often began dismembering each other, smashing cars, spraying paint everywhere or even fitting the wrong equipment'. 5 Ironically, the move to robotised plants eventually increased the need for human labour to 'baby-sit' the robots and make repairs when they broke. Roughly 20 years later, many of the robots remain unused. ${ }^{6}$

\footnotetext{
${ }^{5}$ The Economist, 10 August 1991, 'When GM's robots ran amok'.

${ }^{6}$ Conrad (2001). 
Our overconfidence measures, outlined above, capture precisely the discrepancy in beliefs between the CEO and the market documented in the GM case. Differently from traditional explanations, such as empire building, the CEO truly believes that he is creating value with his (over-)investment.

The implications of overconfidence are, however, more subtle than mere overinvestment. An overconfident CEO persistently feels undervalued by the capital market and is thus reluctant to issue risky securities to finance his projects (Heaton, 2002). This effect is a re-interpretation of traditional Myers-Majluf (1984) type models with asymmetric information. There, the manager has inside information, and good types are reluctant to issue equity since they will be taken for bad types. Here, the overconfident manager thinks he has (positive) inside information, with the same effect on equity issuance. Overconfidence amounts to 'perceived asymmetric information'. The perceived undervaluation induces CEOs to abstain from projects (and even underinvest) when they cannot be financed without tapping the resources of (unbiased) outsiders. In this case, an influx of cash would enable (overconfident) CEOs to undertake these foregone projects. Thus, we do not have a prediction on the level of investment, but overconfidence predicts that investment should be sensitive to cash flow. Moreover, such investment-cash flow sensitivity should be strongest in firms with few internal resources.

As reported in Malmendier and Tate (2004a), the data confirm these predictions: CEOs we classify as overconfident are more sensitive to cash flow in their investment decisions and particularly if internal resources are scarce. Overconfidence thus helps to explain the 'investment-cash flow sensitivity puzzle' in the corporate finance literature.

The investment context is also well-suited to apply our second, press-based measure of overconfidence. In other contexts such as mergers, the press measure is applicable only after accounting for an important endogeneity problem: having completed a merger in the past may change the tenor of future press coverage. ${ }^{7}$ The same concern is much less severe in the context of investment projects, which are numerous and typically receive much less or no press attention. Replicating the results of Malmendier and Tate (2005a) with the press-based measure would jointly corroborate the importance of overconfidence for corporate investment and confirm the validity of the overconfidence measures. We thus apply the press measure to corporate investment, using the standard regression specification:

$$
I_{i t}=\beta_{1}+\beta_{2} Q_{i t-1}+\beta_{3} C_{i t}+X_{i t}^{\prime} B_{4}+\beta_{5} \Delta_{i t}+\beta_{6} C_{i t} \oplus Q_{i t-1}+C_{i t} \oplus X_{i t}{ }^{\prime} B_{7}+\beta_{8} C_{i t} \oplus \Delta_{i t}+\varepsilon_{i t},
$$

where $C$ is cash flow, $Q$ is market value of assets over book value of assets, $X$ is the set of additional controls including stock ownership (as a percentage of total shares outstanding), and total number of vested options (normalised by total number of shares outstanding), firm size, and corporate governance (number of outside directors who are currently CEOs in other companies). $\Delta$ is the press-based overconfidence measure, TOTALdummy, used as a simple managerial fixed-effect. To control for a potential press bias towards positive portrayal, we include the total number of articles mentioning the CEO during the sample period, TOTALmentions, as an additional control. We also include year- and firm-fixed effects as well as (year)*(cash flow) interactions. As in Malmendier and Tate (2005a), we further split the sample into

\footnotetext{
${ }^{7}$ To address this concern in the mergers context (Malmendier and Tate, 2005b), we employ a duration model, restricting the analysis to CEO-firm years up to the first merger (if any).
} 
quintiles from 'least constrained' to 'most constrained' using lagged values of the Kaplan-Zingales index. The overconfidence theory predicts that overconfident CEOs in the most constrained quintile display positive and significant investment-cash flow sensitivity. The results, reported in Table 1, confirm these predictions.

In Malmendier and Tate (2005b), we provide related evidence on the real effects of overconfidence. We find that our measures predict heightened managerial acquisitiveness, particularly in the absence of financial constraints, and show that overconfidence can explain a significant portion of acquiring shareholder value lost in merger deals. The investment and merger results imply that financing decisions are also affected by overconfidence. In Malmendier et al. (2005), we identify directly the financing channel, showing that overconfidence induces a preference for internal over external financing and, conditional on external financing, a preference for debt of equity. Overconfidence thus has the potential to explain both the low-leverage puzzle and pecking-order type behaviour, as well as the variation of these patterns across firms and within firms (Graham, 2000; Shyam-Sunder and Myers, 1999; Myers and Majluf, 1984).

\section{Implications for Corporate Governance}

The possibility of executive overconfidence alters basic conclusions about incentive mechanisms. If CEOs are too optimistic about the value they can generate, then stock and options are not helpful in improving corporate decision-making. Overconfident CEOs do not need incentives to maximise the market value of the firm's equity - that is what they believe they are doing already. Options could even push them towards risk-loving behaviour and investments which are riskier (and lower NPV) than shareholders prefer, especially given that the CEOs already overestimates the expected value of those gambles.

Other incentive devices may work better to root out overinvestment than stock and options. One example is debt. If cash is tied up for debt repayments and the capacity for senior debt is exhausted, the CEO would need to issue risky debt or equity to finance projects. Given that overconfident CEOs perceive their firms to be undervalued, the pre-existing debt will curtail the tendency to overinvest.

More generally, requiring outside approval could counterbalance CEO overconfidence. The 'outsider' could be a vigilant board. The company charter typically specifies a dollar amount beyond which the board has to approve any investment. Lowering the threshold may be a sensible strategy to combat overinvestment due to overconfidence (if boards competently fulfil their monitoring function). An active board that is aware of the firm's investment opportunities could also encourage the $\mathrm{CEO}$ to undertake value-creating projects he may leave on the table when financing constraints are tight. Obviously, limits on rationality and expression of social preferences may affect not only managers but also board members. While overconfidence about the firm's projects may be less likely in external board members (who are not personally hand-picking and designing the projects) than in CEOs, other biases, like escalation of commitment, could affect board decisions as well.

Another important issue is the selection of board members. Do CEOs look for the most able and knowledgeable people? Or do they install yes-men (and maybe particularly so when they are overconfident)? The fundamental problem in evaluating board quality is that the literature has yet to come up with a reliable measure of high-quality boards. Sample limitations - there are still few panel data sets with a long enough time series to analyse changes in corporate governance within firms - and 


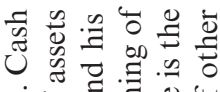
ॠ $\therefore 0$. को

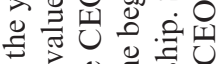
항 을 on

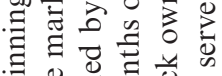

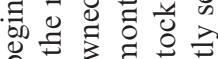

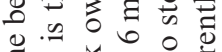
늠

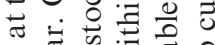
可

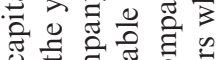

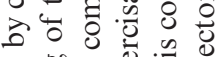

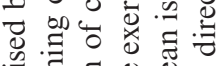
흘.

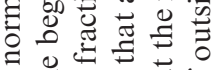

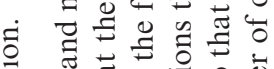
若 造

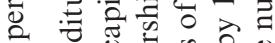

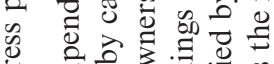

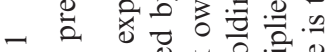

$\frac{\sqrt[0]{0}}{\sqrt[\pi]{6}}$

J

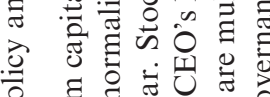

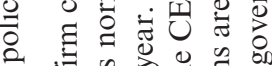

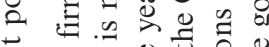

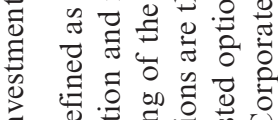

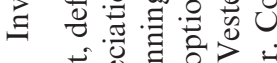
एँ

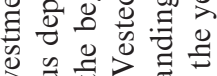

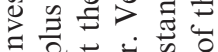

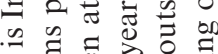

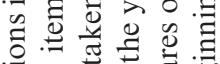

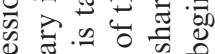

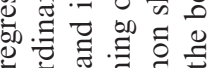

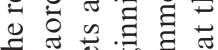

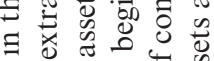
0

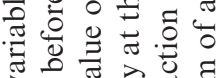

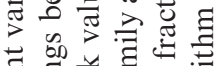

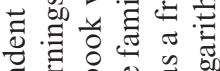

告宫

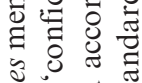

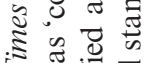
월

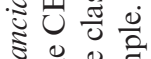
ミ Ð 멸 $\approx . \exists$ क क 昰离离

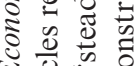
幽. $\approx$ है - 0 菏 ङ

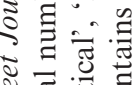
芒䒕 ส $\leq$. ขำ ミ 퐁.

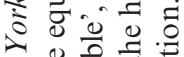
늘 उ. $\stackrel{\pi}{>}$ 为

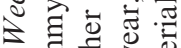
政

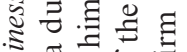
ऊิ $\infty .7$ of

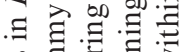

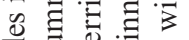

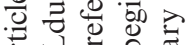
娄过焉

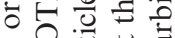

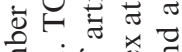

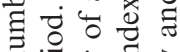
鹃

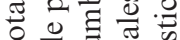
을

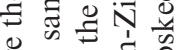

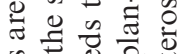
की . चี ¿ 里.

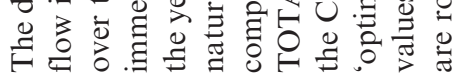

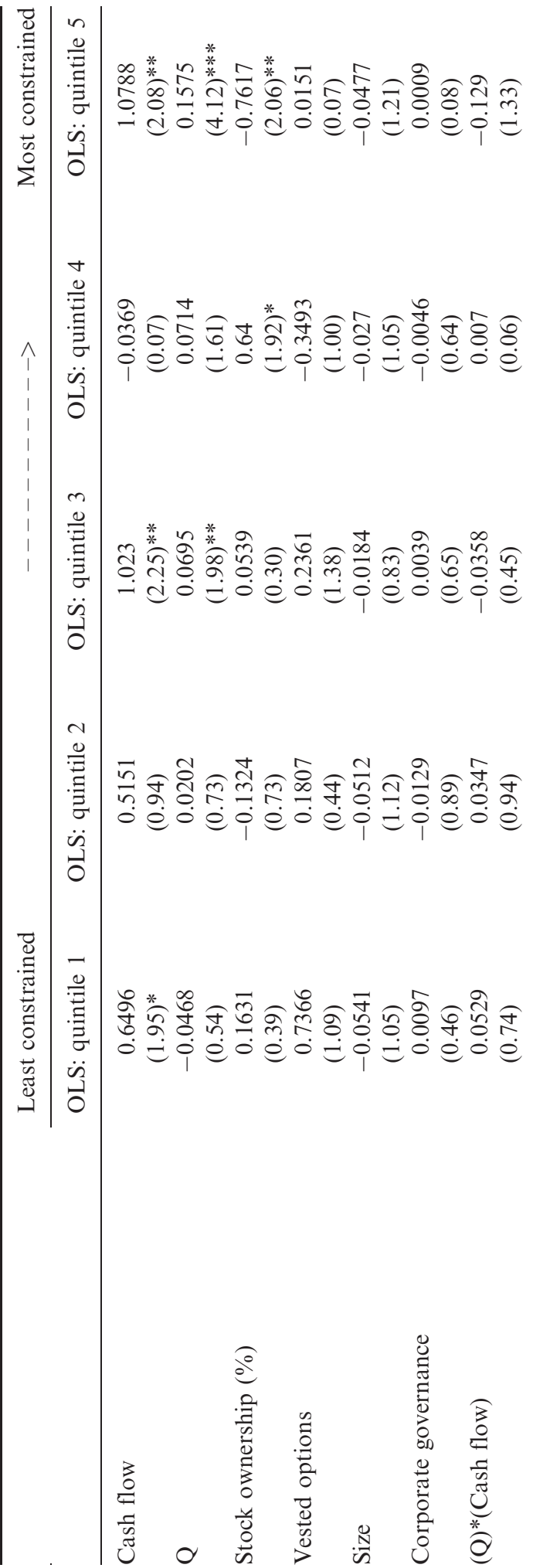




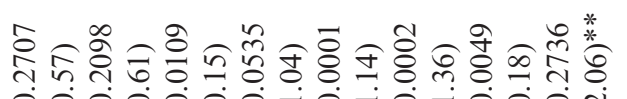
iéi

กิ

I

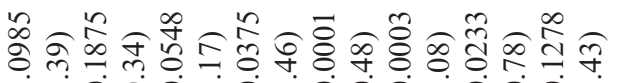

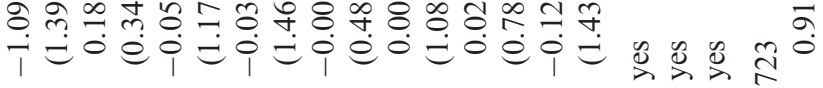

芦

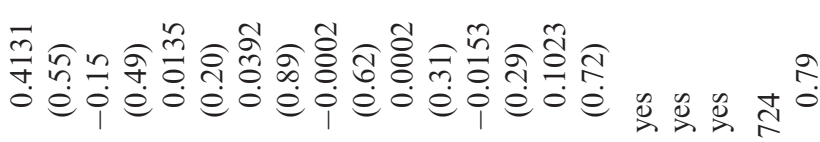

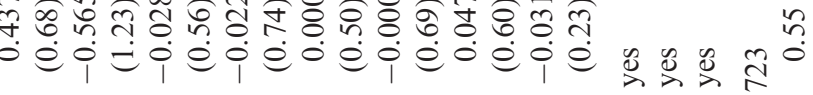

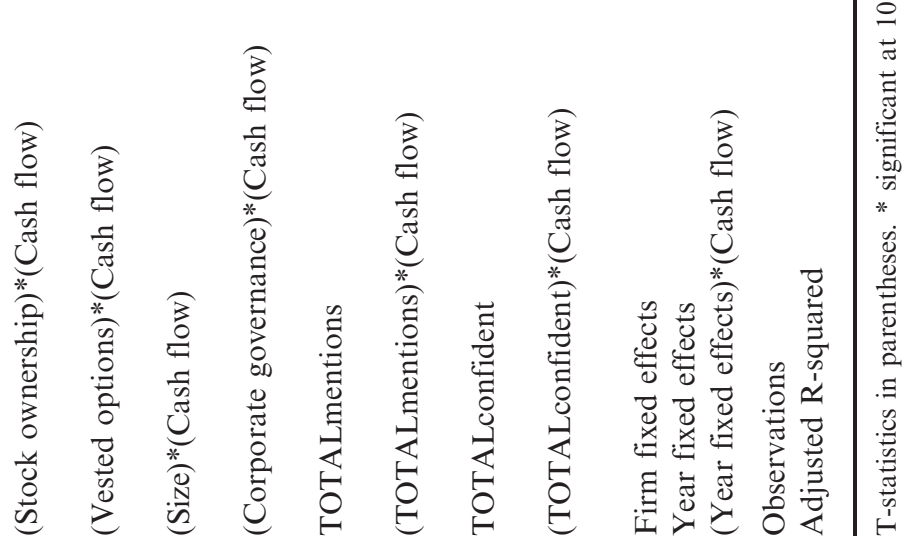


endogenous firm response make progress in this area challenging. Monetary incentives may not be all that matters. The ability to speak the language of the CEO and/or the other board members - or even other-regarding preferences - may be far better determinants of directors' monitoring quality. The behavioural perspective may help the quest for better measures of 'who speaks up in the boardroom'.

\section{References}

Alicke, M. D., 'Global self-evaluation as determined by the desirability and controllability of trait adjectives', Journal of Personality and Social Psychology, Vol. 49, 1985, pp. 1621-30.

Alicke, M. D., Klotz, M. L., Breitenbecher, D. L., Yurak, T. J., et al., 'Personal contact, individuation, and the better-than-average effect', Journal of Personality and Social Psychology, Vol. 68, 1995, pp. 804-25.

Alpert, M. and Raiffa, H., 'A progress report on the training of probability assessors', in D. Kahneman, P. Slovic, and A. Tversky (eds), Judgement under Uncertainty: Heuristics and Biases (Cambridge University Press, 1982), pp. 294-305.

Baker, M. and Wurgler, J., 'The equity share in new issues and aggregate stock returns', Journal of Finance, Vol. 55, 2000, pp. 2219-57.

Baker, M. and Wurgler, J., 'Market timing and capital structure', Journal of Finance, Vol. 57, 2002, pp. 1-32.

Baker, M., Ruback, R. and Wurgler, J., 'Behavioral corporate finance: a survey', in E. Eckbo (ed.), The Handbook of Corporate Finance: Empirical Corporate Finance (New York: Elsevier/ North Holland, forthcoming).

Bazerman, M. H., Judgment in Managerial Decision Making, 5th ed. (Hoboken NJ: John Wiley \& Sons, 2002).

Becker, G., The Economics of Discrimination (Chicago: University of Chicago Press, 1957).

Bergman, N. and Jenter, D., 'Employee sentiment and stock option compensation', Working Paper (MIT, 2005).

Camerer, C. and Lovallo, D., 'Overconfidence and excess entry: an experimental approach', American Economic Review, Vol. 89, no. 1, 1999, pp. 306-18.

Camerer, C. and Malmendier, U., 'Behavioral economics of organizations', in P. Diamond and H. Vartiainen (eds), Economic Institutions and Behavioral Economics, (Princeton NJ: Princeton University Press, Yrjö Jahnsson Foundation, forthcoming).

Conrad, R., 'GM's new vehicle for the future: the ASP'. CNET News.com. 1 September 2001.

Cooper, A. C., Woo, C. Y. and Dunkelberg, W. C., 'Entrepreneurs' perceived chances for success', Journal of Business Venturing Vol. 3, 1988, pp. 97-108.

DellaVigna, S. and Malmendier, U., 'Contract design and self-control: theory and evidence', Quarterly Journal of Economics, Vol. 119, no. 2, 2004, pp. 353-402.

Feather, N. T. and Simon, J. G., 'Attribution of responsibility and valence of outcome in relation to initial confidence and success and failure of self and other', Journal of Personality \& Social Psychology, Vol. 18, no. 2, 1971, pp. 173-88.

Fischhoff, B., Slovic, P. and Lichtenstein, S., 'Knowing with certainty', Journal of Experimental Psychology: Human Perception and Performance, Vol. 3, 1977, pp. 552-64.

Gabaix, X. and Laibson, D., 'Shrouded attributes, consumer myopia, and information suppression in competitive markets', Working Paper (MIT, 2005).

Gervais, S., Heaton, J. B. and Odean, T., 'Overconfidence, investment policy and stock options', Working Paper (Duke University, 2003).

Goel, A. M. and Thakor, A., 'Rationality, overconfidence and leadership', Working Paper No. 00-022 (University of Michigan Business School Faculty, 2000).

Graham, J., 'How big are the tax benefits of debt?' Journal of Finance, Vol. 55, 2000, pp. 1901-42. Hall, B. and Liebman, J., 'Are CEOs really paid like bureaucrats?' Quarterly Journal of Economics, Vol. 113, no. 3, 1998, pp. 653-91. 
Hall, B. and Murphy, K. J., 'Stock options for undiversified executives', Journal of Accounting and Economics, Vol. 33, 2002, pp. 3-42.

Heaton, J. B., 'Managerial optimism and corporate finance', Financial Management, Vol. 31, 2002, pp. 33-45.

Hey, J. D., 'The economics of optimism and pessimism', Kyklos, Vol. 37, no. 2, 1984, pp. 181-205.

Kruger, J., 'Lake Wobegon be gone! The 'below-average effect' and the egocentric nature of comparative ability judgments', Journal of Personality and Social Psychology, Vol. 77, no. 2, 1999, pp. 221-32.

Kunda, Z., 'Motivated inference: self-serving generation and evaluation of causal theories', Journal of Personality and Social Psychology, Vol. 53, 1987, pp. 636-47.

Landier, A. and Thesmar, D., 'Enterpreneurial optimism and financial contracting', Working Paper (NYU, 2004).

Langer, E. J., 'The illusion of control', Journal of Personality and Social Psychology, Vol. 32, 1975, pp. 311-28.

Larwood, L. and Whittaker, W., 'Managerial myopia: self-serving biases in organizational planning', Journal of Applied Psychology, Vol. 62, 1977, pp. 194-98.

Malmendier, U. and Tate, G., 'CEO overconfidence and corporate investment', Journal of Finance, Vol. 60, no. 6, December 2005.

Malmendier, U. and Tate, G., 'Who makes acquisitions? CEO overconfidence and the market's reaction', Working Paper (Stanford University, 2005b).

Malmendier, U., Tate, G. and Yan, J., 'Corporate financial policies with overconfident CEOs', Working Paper, (Stanford University, 2005).

March, J. and Shapira, Z., 'Managerial perspectives on risk and risk taking', Management Science, Vol. 33, no. 11, 1987, pp. 1404-19.

Milburn, M. A., 'Sources of bias in the prediction of future events', Organizational Behavior and Human Performance, Vol. 21, 1978, pp. 17-26.

Miller, D. T. and Ross, M., 'Self-serving biases in the attribution of causality: fact or fiction?' Psychological Bulletin, Vol. 82, no. 2, 1975, pp. 213-25.

Moore, P. G., The manager's struggle with uncertainty', Journal of The Royal Statistical Society Series A, Vol. 149, 1977, pp. 129-65.

Moore, D. A. and Kim, T. G., 'Myopic social prediction and the solo comparison effect', Journal of Personality and Social Psychology, Vol. 85, no. 6, 2003, pp. 1121-35.

Myers, S. and Majluf, N., 'Corporate financing and investment decisions when firms have information that investors do not have', Journal of Financial Economics, Vol. 13, 1984, pp. 187-221.

Nisbett, R. E. and Ross, L., Human Inference: Strategies and Shortcomings of Social Judgment (Engiewood Cliffs NJ: Prentice-Hall, 1980).

Roll, R., 'The hubris hypothesis of corporate takeovers', Journal of Business, Vol. 59, no. 2, 1986, pp. 197-217.

Shyam-Sunder, L. and Myers, S. C., 'Testing static tradeoff against pecking order models of capital structure', Journal of Financial Economics, Vol. 51, 1999, pp. 219-44.

Stigler, G. J., 'The economies of scale', Journal of Law and Economics, Vol. 1, 1958, pp. 54-71.

Svenson, O., 'Are we all less risky and more skillful than our fellow drivers?' Acta Psychologica, Vol. 47, 1981, pp. 143-48.

Van den Steen, E., 'Organizational beliefs and managerial vision', Journal of Law, Economics, and Organization, Vol. 21, no. 1, Spring 2005, pp. 256-83.

Weinstein, N. D., 'Unrealistic optimism about future life events', Journal of Personality and Social Psychology, Vol. 39, 1980, pp. 806-20.

Weinstein, N. D. and Klein, W. M., 'Resistance of personal risk perceptions to debiasing interventions', in T. Gilovich, D. Griffin and D. Kahneman (eds), Heuristics and Biases: the Psychology of Intuitive Judgment (Cambridge: Cambridge University Press, 2002, pp. 313-23.

Yermack, D., 'Do corporations award CEO stock options effectively?' Journal of Financial Economics, Vol. 39, nos. 2-3, 1995, pp. 237-69. 
